\title{
Synthesis and evaluation of cell-permeable biotinylated PU-H71 derivatives as tumor Hsp90 probes
}

\author{
Tony Taldone ${ }^{*} \neq 1$, Anna Rodina ${ }^{\ddagger 1}$, Erica M. DaGama Gomes ${ }^{1}$, \\ Matthew Riolo ${ }^{1}$, Hardik J. Patel ${ }^{1}$, Raul Alonso-Sabadell ${ }^{1}$, Danuta Zatorska ${ }^{1}$, \\ Maulik R. Patel ${ }^{1}$, Sarah Kishinevsky ${ }^{1}$ and Gabriela Chiosis ${ }^{* 1,2,3}$
}

\section{Full Research Paper}

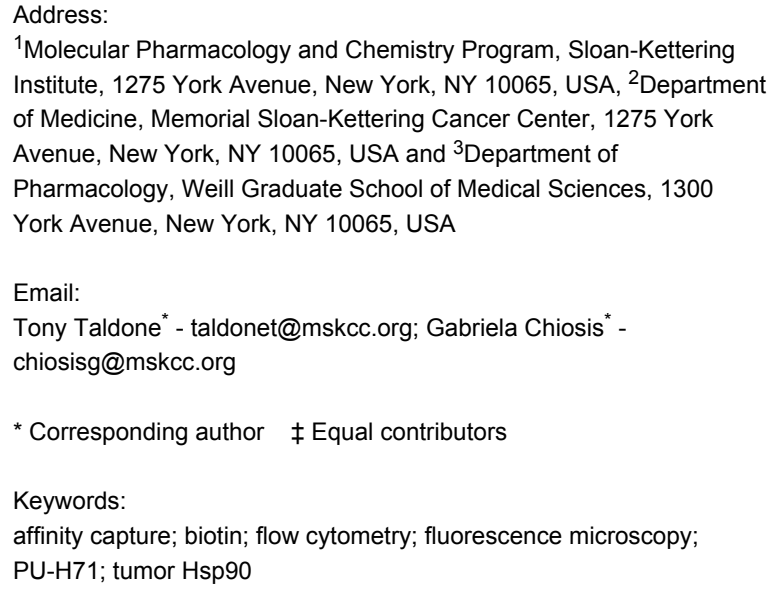

${ }^{1}$ Molecular Pharmacology and Chemistry Program, Sloan-Kettering Institute, 1275 York Avenue, New York, NY 10065, USA, ${ }^{2}$ Department of Medicine, Memorial Sloan-Kettering Cancer Center, 1275 York Avenue, New York, NY 10065, USA and ${ }^{3}$ Department of Pharmacology, Weill Graduate School of Medical Sciences, 1300 York Avenue, New York, NY 10065, USA

Email:

Tony Taldone* - taldonet@mskcc.org; Gabriela Chiosis* -

chiosisg@mskcc.org

* Corresponding author $\ddagger$ Equal contributors

Keywords:

affinity capture; biotin; flow cytometry; fluorescence microscopy;

PU-H71; tumor Hsp90

Beilstein J. Org. Chem. 2013, 9, 544-556. doi:10.3762/bjoc. 9.60

Received: 10 October 2012

Accepted: 20 February 2013

Published: 15 March 2013

This article is part of the Thematic Series "Synthetic probes for the study of biological function".

Guest Editor: J. Aubé

(C) 2013 Taldone et al; licensee Beilstein-Institut. License and terms: see end of document.

\begin{abstract}
The attachment of biotin to a small molecule provides a powerful tool in biology. Here, we present a systematic approach to identify biotinylated analogues of the Hsp90 inhibitor PU-H71 that are capable of permeating cell membranes so as to enable the investigation of Hsp90 complexes in live cells. The identified derivative $\mathbf{2 g}$ can isolate Hsp90 through affinity purification and, as we show, represents a unique and useful tool to probe tumor Hsp90 biology in live cells by affinity capture, flow cytometry and confocal microscopy. To our knowledge, $\mathbf{2} \mathbf{g}$ is the only reported biotinylated Hsp90 probe to have such combined characteristics.
\end{abstract}

\section{Introduction}

Heat shock protein 90 (Hsp90) is a molecular chaperone that functions to properly fold proteins to their active conformation through its ATPase activity [1]. These client proteins include many that are involved in malignant cell transformations (i.e., HER2, EGFR, mutant ER, HIF1 $\alpha$, Raf-1, AKT, mutant p53).
As a result of this, as well as the ability to block multiple signaling pathways through inhibition of a single target, Hsp90 has become one of the most pursued molecular targets for anticancer therapy $[2,3]$. As a testament to this, there are numerous ongoing clinical trials evaluating Hsp90 inhibitors from a 
variety of chemotypes [4]. Although there are potentially numerous ways to block the activity of Hsp90, the most successful to date, as exemplified by its exclusivity in mode of action by those advanced to clinical trials, has been the ATPcompetitive inhibitors that bind to the $\mathrm{N}$-terminal nucleotide binding pocket $[4,5]$.

Hsp90 belongs to the family of GHKL ( $G=$ DNA gyrase subunit $\mathrm{B} ; \mathrm{H}=\mathrm{Hsp} 90 ; \mathrm{K}=$ histidine kinases; $\mathrm{L}=\mathrm{MutL}$ ) ATPases, which is distinguished by a unique bent shape of its nucleotide binding pocket [6]. This distinctive shape has enabled for the design of highly selective ATP-competitive inhibitors of Hsp90. Through the efforts of multiple drugdiscovery groups, many classes of inhibitors have been identified $[3,5,7,8]$. While much is known about the general types of structures that inhibit Hsp90 and their structure-activity relationship, less is understood about Hsp90 tumor biology. As a result we and others have been actively engaged in the synthesis of chemical tools designed to probe the function of Hsp90 in transformed systems [9-11]. One class of Hsp90 inhibitors of interest is the purine scaffold, including its representative PU-H71 (1a). This agent, currently in clinical investigation for cancer, binds to the $\mathrm{N}$-terminal nucleotide binding pocket of Hsp90 [12].

We have shown that PU-H71 selects for tumor Hsp90 species, and therefore labeled derivatives of PU-H71 may be used to specifically dissect, in a tumor-by-tumor manner, the abundance and the functions of the oncogenic Hsp90 [13,14]. Specifically, these tools, which may selectively retrieve only those Hsp90 complexes that are "available" for inhibition, will allow for a better characterization of the "oncogenic Hsp90", both with regards to its onco-client protein content and the nature of its distinct post-translational modifications. This is in contrast to immunoprecipitation of Hsp90, which we have shown to identify and isolate both "oncogenic Hsp90" (i.e., PU-H71-binding) and "housekeeping Hsp90" (i.e., PU-H71 nonbinding) complexes.

The attachment of biotin to a small molecule provides a powerful tool in biology. As research tools, biotin-labeled chemical tools have the potential to extend the study of single targets to a particular class of molecules or even to an entire proteome. In addition, the development of biotinylated chemical tools that penetrate live cells and, thus, are designed both to probe and to modulate the activity of biomolecules in live biological systems, allows for a type of "live biochemistry and biology" that can complement traditional biochemical and biological approaches by promoting molecular characterization of biomolecules both in vitro and within their natural biological contexts.
In one application, biotinylated probes may be subjected to streptavidin-containing beads to identify potential direct and indirect interactors of the small molecule through affinity capture. Streptavidin binds to biotin in the strongest noncovalent interaction known, with $K_{\mathrm{d}} \sim 1 \times 10^{-14} \mathrm{M}$. As we have already shown with PU-H71 attached directly onto beads, its ability to bind to Hsp90 in client-protein-bound complexes may be used to identify and analyze the drivers of oncogenic transformations on a tumor-by-tumor basis [13]. Therefore, we believe that there is considerable value in preparing biotinylated analogues of PU-H71 (1a) with the ability to permeate cell membranes so as to enable the investigation of oncogenic Hsp90 complexes in live cells. In contrast to PU-H71 beads, which are limited to cell homogenates, these compounds may be further used to investigate Hsp90 complexes in live cells, which represents a more physiologically relevant state. These tools also have use in flow cytometry and microscopy, whereby fluorescently labeled antibodies to biotin are used, as we describe below.

\section{Results and Discussion Design and synthesis of biotinylated purine scaffold Hsp90 probes}

Geldanamycin (GM) is a benzoquinone ansamycin first isolated from a fermentation broth of Streptomyces hygroscopicus [15] and was the first reported Hsp90 inhibitor [16]. It has played a paramount role as a probe molecule to investigate Hsp90 biology, and in fact the attachment of GM to solid support enabled the identification of Hsp90 as the target of its anticancer activity through affinity purification [16]. Biotinylated GM has also been synthesized and has been proposed as a tool to identify proteins other than Hsp90 that GM may directly bind to [17]. Since the available evidence suggests GM cannot efficiently trap Hsp90 in client-bound complexes [13,18], it appears that GM-biotin is of limited use beyond identifying potential direct interactors. In contrast, PU-H71 (1a) is highly selective for Hsp90 and furthermore can efficiently bind to and trap Hsp90 in client-bound complexes allowing for the identification of global tumor Hsp90 proteomes by mass spectrometry [13].

We therefore set out here to design a series of biotinylated analogues derived from the purine scaffold Hsp90 inhibitor PU-H71 (1a) with the purpose of identifying compounds capable of permeating cancer-cell membranes, binding selectively to intracellular oncogenic Hsp90 in live cancer cells, and able to trap and isolate Hsp90 bound to tumor-specific oncoclient proteins. Because the biotin tag enables pull-down experiments through subsequent binding to streptavidin or avidin, a further requirement for our probe is that the linker be of sufficient length to enable the concomitant binding to Hsp90 and 
streptavidin. Thus, in the design of these probes, the type of linker, as well as its length, was systematically altered so as to identify compounds that demonstrate such combined properties (Figure 1).

As such we have prepared a number of biotinylated analogues, derived from $\mathbf{1 a}$ and $\mathbf{1 b}$, containing linkers of various lengths (1 to 17 atoms) and hydrophobicities (polyethylene-, amide- and/ or alkyl-containing). In addition, an amine-linked biotin analogue 2a, which we have reported previously [9], was also prepared for comparison purposes. This differs from the others by the presence of an ionizable amine in the linker region. Although 2a is a potent Hsp90 binder, it is less effective at capturing Hsp90 complexes and has poor cancer-cell permeability (Figure 2) and was therefore of limited use and served as a further impetus for the synthesis of the novel probes described here.
A critical factor in the design of biotinylated purine-scaffold Hsp90 probes is the site of attachment of biotin. From previous work including X-ray crystal structure [19], extensive SAR [20,21], and docking experiments [9], the N9-position of the purine scaffold was shown to be an ideal site for attachment since it is directed towards the solvent. Furthermore, the amino group of 1a or the desisopropyl analogue $\mathbf{1 b}$ provided a convenient handle with which to attach biotin directly or via a linker through an amide bond. We chose to make analogues of both $1 \mathrm{a}$ and $\mathbf{1 b}$ because the isopropyl group in 1a may result in considerable effects on cell-permeability properties due to its increased lipophilicity, while having little effect on the affinity for Hsp90. While it is essential that the linker be of sufficient length to enable the concomitant binding to Hsp90 and streptavidin, it is also important that it is not exceedingly long for two reasons. First, the possibility and extent of nonspecific binding increases with longer linkers. Second, longer linkers result in a

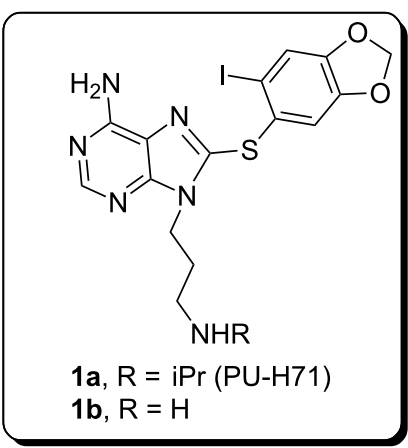

$2 a$

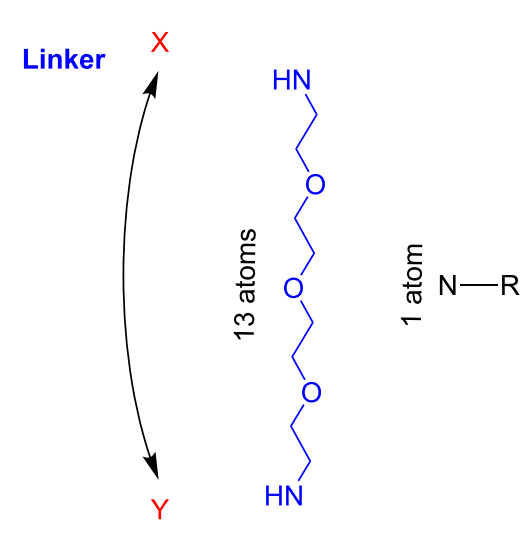

Trap Hsp90 in complex with onco-client proteins

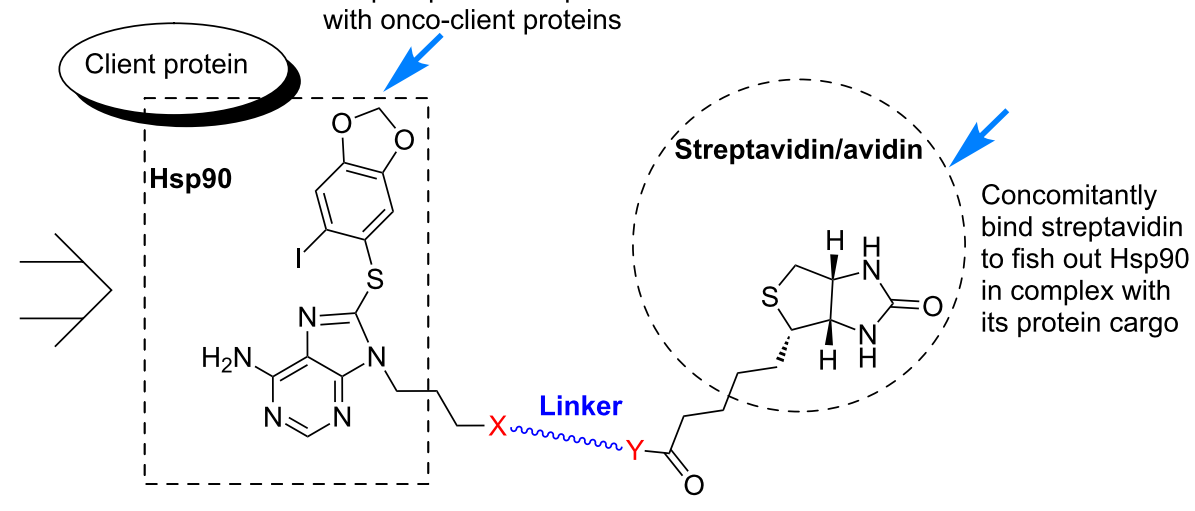

2b, $\mathrm{R}=\mathrm{iPr} \quad$ 2d, $\mathrm{R}=\mathrm{iPr}$

2e, $R=H$

2f, $\mathrm{R}=\mathrm{iPr}$

$2 \mathrm{~g}, \mathrm{R}=\mathrm{H}$

2h, $\mathrm{R}=\mathrm{iPr}$

2i, $\mathrm{R}=\mathrm{H}$

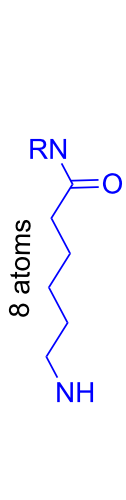<smiles>[R19]C(=O)CCCCCNC(=O)CCCCCN</smiles>

Figure 1: Design of the biotinylated Hsp90 probes based on PU-H71 (1a). 


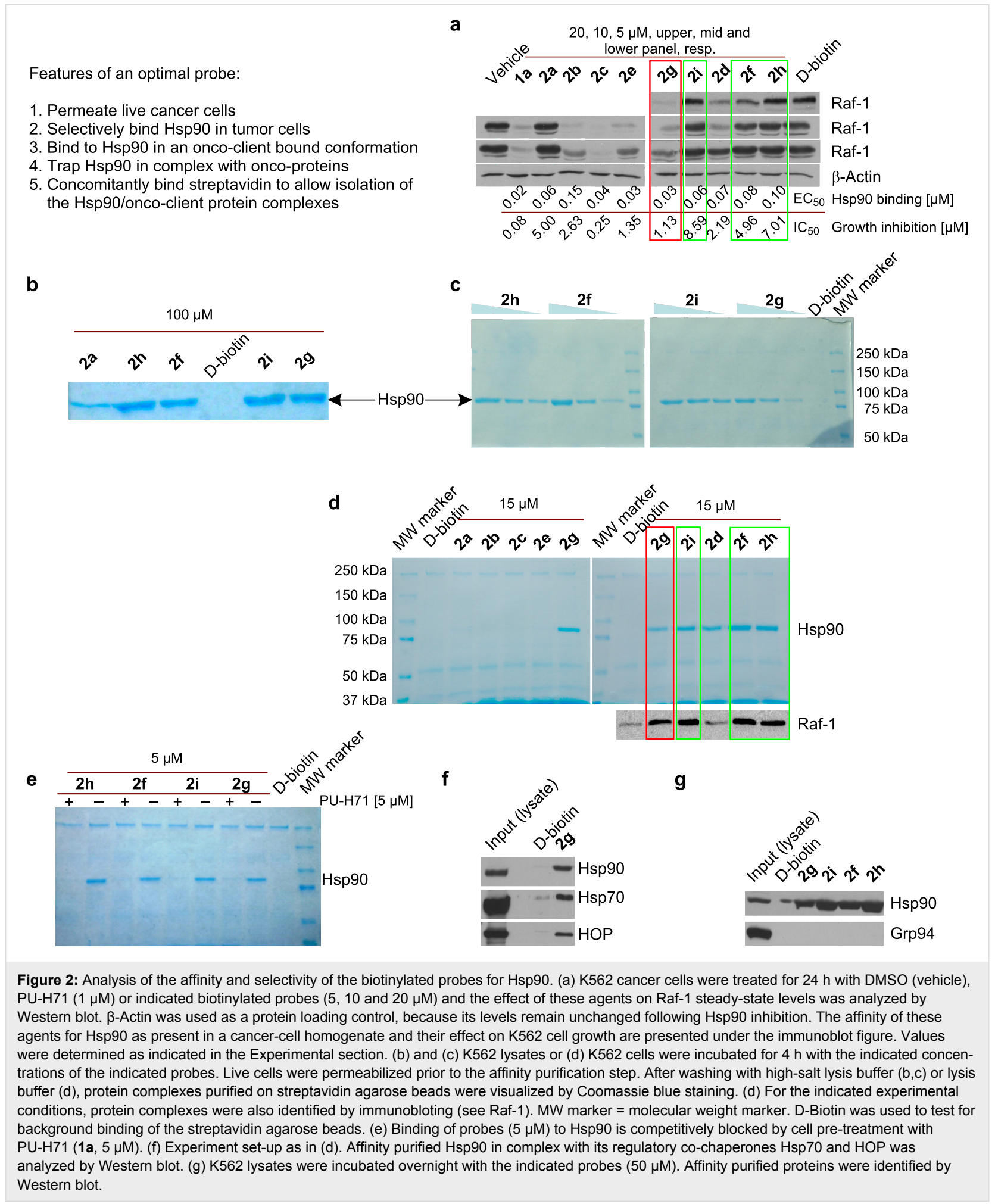

higher molecular weight of the compound, which can adversely affect their permeability across cell membranes.

The synthesis of the biotinylated molecules is shown in Scheme 1 and in each case occurs in a single step from 1a or 1b. $\mathbf{2 b}$ and $\mathbf{2 c}$ were prepared from $\mathbf{1 a}$ or $\mathbf{1 b}$, respectively, in $99 \%$ and $56 \%$ yield by DCC coupling with D-biotin under soni-

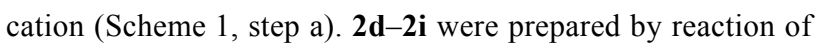
1a or 1b with three different commercially available $\mathrm{N}$-hydroxysuccinimide (NHS) active ester containing biotin 
molecules (Scheme 1, steps b-d). Whereas reactions with $\mathbf{1 b}$ occurred at $\mathrm{rt}$ and were complete after $1 \mathrm{~h}$ giving the desired products in good yield (72-88\%), reactions with 1a required heating at $35^{\circ} \mathrm{C}$ and were incomplete after $6 \mathrm{~h}$ as evidenced by recovery of a significant amount of unreacted starting material. The yields of isolated products ranged from $29-41 \%$. 2d and $2 \mathrm{e}$ were prepared from EZ-Link ${ }^{\circledR}$ NHS-LC-Biotin (Scheme 1, step b). $2 \mathrm{f}$ and $\mathbf{2 g}$ were prepared from EZ-Link ${ }^{\circledR}$ NHS-LC-LCBiotin (Scheme 1, step c). $\mathbf{2 h}$ and $\mathbf{2 i}$ were prepared from EZ-Link ${ }^{\circledR}$ NHS-PEG 4 -Biotin (Scheme 1, step d). 2a was prepared as reported previously [9], by amination of the corresponding bromide with EZ-Link ${ }^{\circledR}$ Amine- $\mathrm{PEO}_{3}$-Biotin.

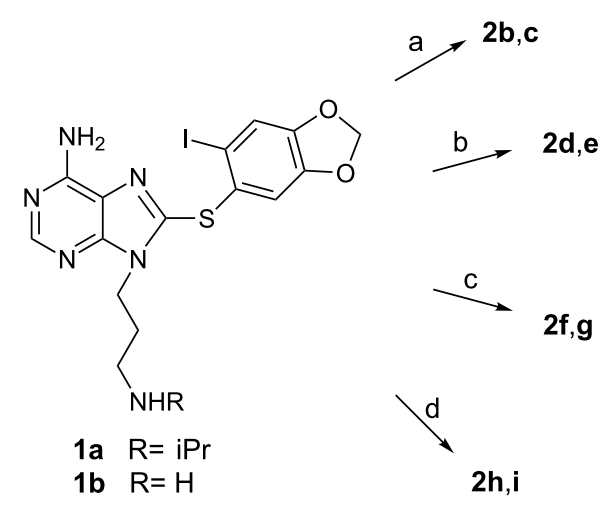

Scheme 1: Reagents and conditions: (a) D-biotin, DCC, DMAP, $\mathrm{CH}_{2} \mathrm{Cl}_{2}$, sonicate; (b) EZ-Link ${ }^{\circledR} \mathrm{NHS}$-LC-Biotin, DIEA, DMF, $35^{\circ} \mathrm{C}$ or rt; (c) EZ-Link ${ }^{\circledR}$ NHS-LC-LC-Biotin, DIEA, DMF, $35^{\circ} \mathrm{C}$ or rt; (d)

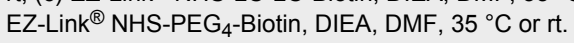

It should be noted that in each of the products $(\mathbf{2 b}, \mathbf{2 d}, \mathbf{2 f}, \mathbf{2 h})$ derived from 1a it was not immediately clear whether these were a mixture of two compounds or rotamers, despite the seeming unambiguity in the synthesis. While HPLC showed a single homogeneous peak, the NMR spectrum was very complicated. To settle this, $\mathbf{2 d}$ was prepared by an alternate synthesis (Scheme 2). DCC coupling of 1a with 6-Boc-aminocaproic acid yielded 3 following removal of the Boc group, which was further reacted with D-biotin to give a product with identical NMR and HPLC profile to 2d, confirming that a mixture of two rotamers was present and not a mixture of two compounds. Additionally, intermediate 3 also demonstrates a complex NMR spectrum indicative of the presence of two rotamers. All of this shows that, unlike the proton, the isopropyl group is bulky enough to hinder rotation of the tertiary amides and to enable identification of two rotamers by NMR [22].

\section{Biological evaluation of the biotinylated Hsp90 probes}

As indicated above, there are several requirements for a biotinylated probe to be useful in dissecting Hsp90 tumor biology in

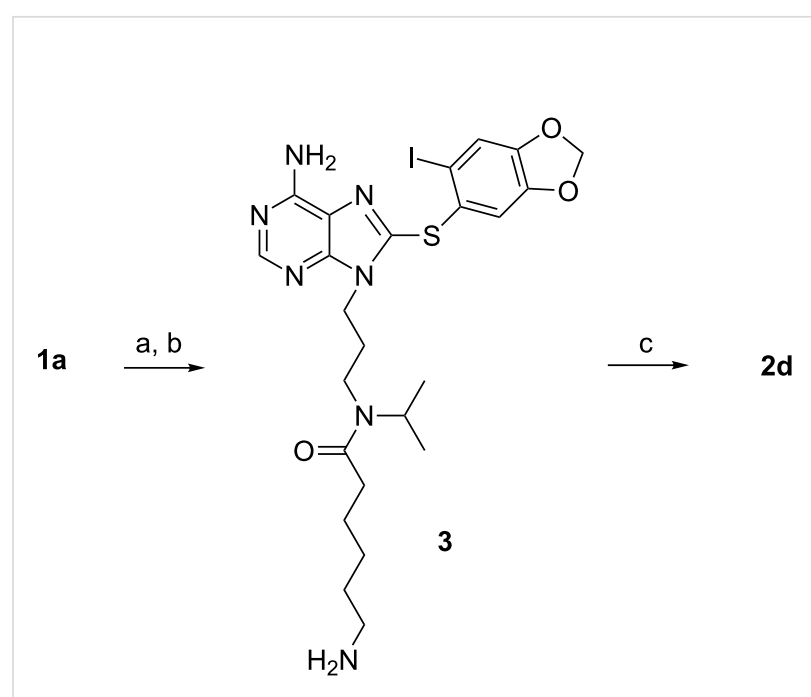

Scheme 2: Reagents and conditions: (a) 6-Boc-aminocaproic acid, DCC, DMAP, $\mathrm{CH}_{2} \mathrm{Cl}_{2}$, rt; (b) TFA, $\mathrm{CH}_{2} \mathrm{Cl}_{2}$, rt; (c) D-biotin, DCC, DMAP, $\mathrm{CH}_{2} \mathrm{Cl}_{2}$, sonicate.

live cells. First, the probe should retain selective and tight binding to tumor Hsp90. Second, it should permeate live cells and while inside the cell, should bind to the oncogenic Hsp90. Upon cell permeabilization, the probe should retain Hsp90 binding and concomitantly bind to streptavidin allowing for subsequent isolation of Hsp90. Third, if isolation of oncogenic Hsp90 in complex with its tumor-specific client proteins is the desired outcome, the probe should also trap and lock the Hsp90/ protein complex, so that it is maintained throughout the subsequent permeabilization and purification steps.

\section{Requirement 1: Retain tight binding to tumor Hsp90}

To ensure the biotinylated compounds still retained affinity for tumor Hsp90, they were each evaluated in a fluorescence polarization (FP) assay by using a cancer-cell homogenate (i.e., SKBr3 human breast cancer lysate). This assay measures competitive binding to tumor cell Hsp90 complexes [23]. Each compound retained a good affinity for Hsp90, with values ranging from 30 to $150 \mathrm{nM}$ (Figure 2a, Hsp90 binding). Two general trends were observed. First, compared to the PU-H71 analogues, the desisopropyl analogues bound on average with approximately 2 -fold greater affinity (i.e., $\mathbf{2 c}$ versus $\mathbf{2 b}, \mathbf{2 e}$ versus $\mathbf{2 d}, \mathbf{2}$ g versus $\mathbf{2 f}, \mathbf{2} \mathbf{i}$ versus $\mathbf{2 h}$ ), despite the fact that both 1a and 1b bound Hsp90 with similar affinity (24.5 versus $26 \mathrm{nM}$ for $\mathbf{1 a}$ and $\mathbf{1 b}$, respectively). This is likely a result of increased steric crowding of the bulky isopropyl group in analogues of 1a. Second, in terms of the linkers, the carbon series appeared to have a somewhat higher Hsp90 affinity than the ethylene glycol series (i.e., $2 \mathbf{d}$ and $\mathbf{2 f}$ versus $\mathbf{2 h} ; \mathbf{2} \mathbf{e}$ and $\mathbf{2 g}$ versus $\mathbf{2 i}$ ). In sum however, all of the compounds retained good 
affinity for Hsp90, supporting our notion for the ideal site of biotinylation, and were thus suitable for further analysis.

\section{Requirement 2: Permeate live cancer cells and bind to oncogenic Hsp90}

Having shown that each of the prepared biotinylated molecules retained good affinity for Hsp90, we next evaluated these compounds in two functional read-outs that together measure that the probe has entered a live cancer cell and once inside the cell, has bound to a substantial fraction of oncogenic Hsp90 molecules. Specifically, K562 is a human leukemia cell line dependent on Hsp90 for survival [13]. Thus, in such cells, occupancy of Hsp90's regulatory pocket by small molecules results in inhibition of its cancer-sheltering properties, leading to cell-growth inhibition associated with degradation of Hsp90-chaperoned onco-proteins. These, such as is the case for Raf- 1 in K562 cells, become ubiquitinated and targeted for proteasomal degradation leading to a decrease in their steady-state levels (Figure 2a, Raf-1) [24].

While the biotinylated analogues displayed decreased potency compared to 1a, it was clear from these results that some were capable of entering live cells in such concentrations as to substantially occupy the oncogenic Hsp90 sites (Figure 2a, for derivatives $\mathbf{2 b}, \mathbf{2 c}, \mathbf{2 e}, \mathbf{2 g}$ and $\mathbf{2 d}$ almost complete Raf-1 degradation associated with cell-growth inhibition in a similar concentration range). Other derivatives, such as $\mathbf{2 i}, \mathbf{2} \mathbf{f}$ and $\mathbf{2 h}$ failed to exhibit such properties (Figure 2a).

From the results, several conclusions concerning linker length and type can be drawn. In general, as the chain length increased, the ability to enter into the cancer cell decreased. With regards to linker nature, the polyethylene glycol linker containing derivatives (i.e., $\mathbf{2 a}, \mathbf{2} \mathbf{h}$ and $\mathbf{2 i}$ ) performed poorest by this measure. Unexpectedly, derivatives $\mathbf{2 g}$ and $\mathbf{2 f}$ both containing the same 15-atom linker and differing only by the presence of $\mathrm{H}$ (on derivative $\mathbf{2 g}$ ) or iPr (on derivative $\mathbf{2 f}$ ) exhibited distinct behaviors, with only $\mathbf{2 g}$ appearing to be substantially taken up by the cancer cell.

\section{Requirement 3: Bind concomitantly to Hsp90 and streptavidin}

Having identified which compounds were capable or not of permeating live cancer cells, we next wanted to determine whether the chain length was optimal to maintain concomitant binding to Hsp90 and streptavidin, so as to allow for isolation and identification of Hsp90/onco-client complexes from cancer cells. For this purpose, K562 lysates (Figure $2 \mathrm{~b}$ and c) were incubated with the biotinylated ligands and the complexes captured on streptavidin beads. To test for the probe's selectivity, pull-downs were performed with increasing concentra- tions of biotinylated derivatives (10, 25 and $50 \mu \mathrm{M}$; Figure $2 \mathrm{c}$ ). Additionally, affinity-purified complexes were washed with high-salt buffer to remove Hsp90-bound co-chaperones and client proteins (Figure $2 \mathrm{~b}$ and $\mathrm{c}$ ).

Of the new biotin derivatives, only $\mathbf{2 h}, \mathbf{2 f}, \mathbf{2} \mathbf{g}$ and $\mathbf{2 i}$ performed better than 2a and isolated substantial amounts of Hsp90 (Figure $2 \mathrm{~b}$ and $\mathrm{c}$ ). We were unable to affinity purify Hsp90 with derivatives $\mathbf{2 b}, \mathbf{2 c}$ and $\mathbf{2 e}$, indicating that while these compounds entered the cancer cell and bound to intracellular Hsp90 (Figure 2a), the linker was of unfavorable length and did not allow for concomitant binding to streptavidin through the biotin end of the probe. Consequently, isolation of Hsp90 from the cell homogenate failed with these biotinylated probes. As reported, 2a containing a 13-atom linker was a modest probe for affinity purifications (Figure 2b and [9]), suggesting that for Hsp90, a linker longer than 13-atoms, and more exactly of 15-atoms or longer, was needed to maintain concomitant Hsp90 and streptavidin binding.

\section{Requirement 4: Trap Hsp90 in an onco-client-bound conformation and isolate the endogenous Hsp90/ onco-client complexes from live cells}

To test for the probes' ability to isolate Hsp90 in secondary and tertiary complexes, such as those containing onco-client proteins, affinity purifications were also performed from live K562 cancer cells (Figure 2d). In such a case, the biotinylated tool is added to live cells where the compound binds to Hsp90 in an onco-client-bound conformation, locking and preserving the endogenous Hsp90/protein complexes throughout the subsequent experimental steps (i.e., permeabilization). In contrast, when adding a biotinylated tool to cell homogenates, one may encounter two potential limitations. First, due to the dynamic nature of the Hsp90/client protein interactions, the endogenous complexes may be lost during the homogenization process and thus, pull-downs from homogenates may miss important interactors. Second, during homogenization, certain proteins may lose their well-regulated conformation and potentially aggregate. Such misfolded proteins are prone to be captured by chaperones resulting in "false positives" (i.e., nonendogenous Hsp90 client proteins). False positives increase the "background" on the affinity resin, and the higher the background, the poorer the identification of relevant endogenous Hsp90 complexes will be. Therefore, while it is true that following the addition of the biotinylated tool to cells, these are permeabilized or fixed/ permeabilized and thus no longer alive, the capture of the oncogenic Hsp90 complexes takes place in the live cell.

Consequently, in live-cell experiments, cells were first incubated with the biotinylated PU-H71 derivatives to trap and maintain the onco-client complexed to Hsp90. Next, cells were 
ruptured into a physiological buffer containing molybdate. The purpose of this step is to release the proteins from the cell yet maintain the Hsp90/onco-client protein complexes intact. Following capture of these complexes on the streptavidin beads, complexes were applied to a denaturing gel, then probed by both Coomassie stain (Figure 2d, top panel) and immunoblot (Figure 2d, bottom panel Raf-1 blot). The Coomassie blue stained gels of these pull-downs showed a single band at approximately $90 \mathrm{kDa}$ for derivatives $\mathbf{2 g}, \mathbf{2 i}, \mathbf{2 d}, \mathbf{2 f}$ and $\mathbf{2 h}$ (Figure $2 \mathrm{~d}$ ), which was competitively blocked by pretreatment of cells with a soluble ligand (Figure 2e) indicating concomitant binding to Hsp90 and streptavidin, and moreover confirming selective and strong binding between these probes and Hsp90.

Analogues of 1-atom linker (2b and $\mathbf{2 c}$ ) and 8-atom linker (2d and 2e) showed a faint band or no band at $90 \mathrm{kDa}$, a finding similar to experiments performed in cell homogenates, indicating that the linker was of inadequate length for the purpose of affinity purification. Derivative 2d behaved erratically over several experiments, showing either faint or no isolation of Hsp90 (Figure 2d and not shown). We potentially attribute such behavior to interbatch variability in the loading capacity and nature of the streptavidin beads. $2 \mathbf{d}$ being of borderline characteristics with regards to chain (i.e., eight atoms in length and containing the sterically constraining iPr) and cancer-cell permeability (Figure 2a) would fail to isolate Hsp90 in amounts visible by Coomassie staining when low-capacity streptavidin beads are used. As such, we advise against the use of this derivative as a chemical tool. Most efficient at isolating Hsp90 in complex with an onco-client protein such as Raf-1 were derivatives with 15 -atom (2f and $\mathbf{2 g}$ ) and 17 -atom linkers (2h and 2i) (Figure 2d, Hsp90 and Raf-1). From cells, 2g affinity purifies Hsp90 in complex with its regulatory cochaperones, Hsp70 and HSP-organizing protein (HOP) [1,2,13] (Figure 2f).

It is important to note that the affinity purification strength of the biotinylated probes is weaker than that of directly solidsupport-linked PU-H71. This is likely a consequence of the solid-support loading capacity. While direct attachment of a ligand to the bead can result in high local concentrations of ligand, the attachment of ligand indirectly by means of biotinstreptavidin is limited by the concentration of streptavidin available on the solid support. It is obvious that much lower numbers of bulky streptavidin molecules can be attached on any solid support when compared to a low-molecular-weight ligand, such as PU-H71. Therefore, for isolation and identification of entire Hsp90 proteome isolations by mass spectrometry, as we recently reported [13], the beads containing PU-H71 directly attached by a covalent link remain the most efficient probe, and we continue to recommend their use for such purposes.
Interestingly, when tested for Hsp90 paralogue-selectivity, we noted for the $\mathbf{2 g}, \mathbf{2 i}, \mathbf{2 f}$ and $\mathbf{2 h}$ derivatives a substantial preference for the affinity purification of the cytosolic Hsp90 over the endoplastic reticulum (ER) paralogue, Grp94 (Figure 2g). This is a surprising finding, because PU-H71 is a pan-Hsp90 inhibitor that binds equally well to the cytosolic and the ER paralogues (Chiosis G, personal communication). We tested the affinity of $\mathbf{2 g}, \mathbf{2 i}, \mathbf{2 f}$ and $\mathbf{2 h}$ for the two paralogues, and identically to the parent ligand PU-H71, we determined little preference for Hsp90 over Grp94 (45 versus $451 \mathrm{nM}$ for $\mathbf{2 g}$; 83 versus $226 \mathrm{nM}$ for $\mathbf{2 i}$; 98 versus $210 \mathrm{nM}$ for $\mathbf{2 f}$; 137 versus $313 \mathrm{nM}$ for 2h). These findings indicate that the selectivity profile was unlikely imparted by the ligand. More likely, the ligand binds to both Hsp90 and Grp94 in the cell extract; however, isolation of the Grp94 complex on the streptavidin beads fails because of the inappropriate nature of the linker. Such was the case for probes $\mathbf{2 b}$ and $\mathbf{2 c}$ (see above), which, although they both bound effectively to Hsp90, could not concomitantly bind Hsp90 and streptavidin, and thus isolation of Hsp90 from extracts failed with such probes.

\section{Potential uses of the biotinylated Hsp90 probes}

Having shown that the probes bind to tumor Hsp90, we went on to demonstrate several potential uses for probe $\mathbf{2 g}$. In addition to affinity-purification of oncogenic Hsp90 from distinct tumors, the biotinylated probes are useful to measure the drugaccessible tumor Hsp90 by both flow cytometry and microscopy techniques. We exemplify here such use in the K562 leukemia cells in the determination of cell-surface (Figure 3a) and intracellular (Figure 3b and c) Hsp90 by flow cytometry and by fluorescent microscopy (Figure 3c). For the measurement of intracellular Hsp90, the use of digitonin was effective in allowing the entry of the antibiotin antibody for probe detection (Figure 3b). Both digitonin and saponin can be used to reversibly open cellular pores and allow antibody entry, thus allowing for retention of cell viability, if this is desired [25]. Staining with CD45, a plasma membrane protein, was used as a positive control for detection of cell-surface Hsp90 (Figure $3 \mathrm{a}$ and $\mathrm{b}$ ). The contribution to the signal of endogenous levels of biotin in the cell was accounted for by the use of cells stained with a fluorescently labeled antibiotin antibody (control, Figure 3).

\section{Conclusion}

In our continuing efforts to develop tools that may be used to better understand tumor Hsp90 biology, we have prepared a series of biotinylated analogues of the purine scaffold Hsp90 inhibitor PU-H71 (1a) and its desisopropyl analogue 1b. The goal of this study was to optimize probe 2a [9] and develop analogues capable of efficiently permeating the cancer cell membrane so that they may be used as tools to investigate onco- 
a
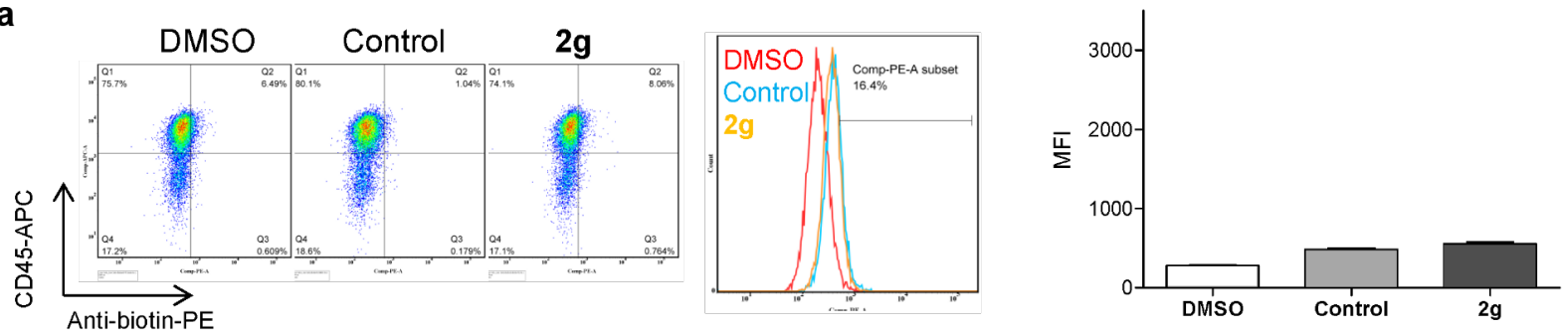

b
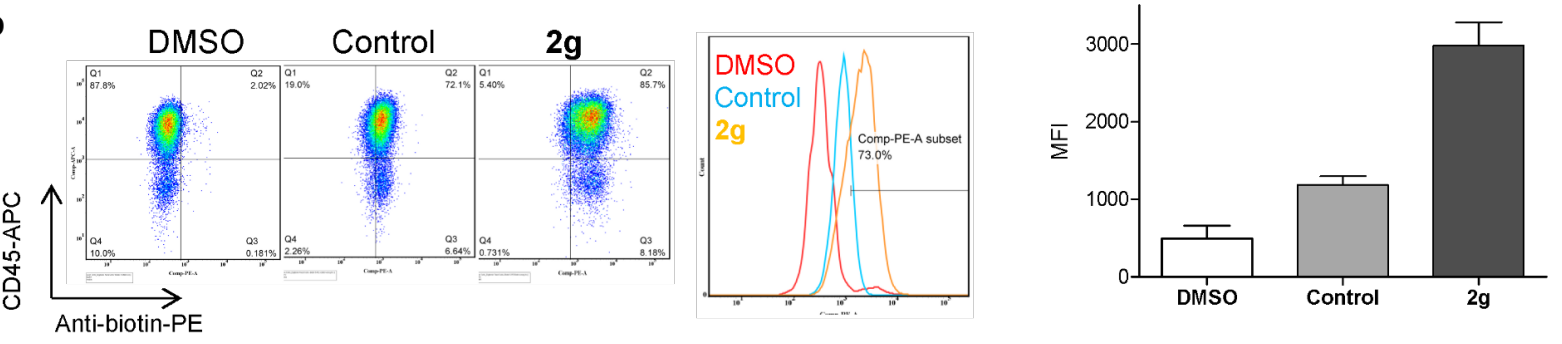

C
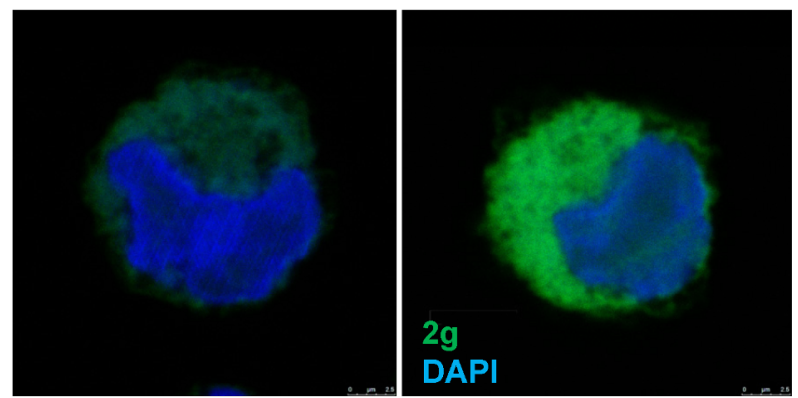

Figure 3: Use of probe $\mathbf{2 g}$ to detect oncogenic Hsp90 by flow cytometry (a) and (b) and by microscopy (c). For (b) and (c) cells were permeabilized with digitonin. DMSO, cells treated with vehicle only; control, cells treated with vehicle and stained with antibiotin-PE for flow cytometry and antibiotinFITC for fluorescent microscopy; $\mathbf{2 g}$, cells treated with probe $\mathbf{2} \mathbf{g}$ and stained with antibiotin-PE for flow cytometry and antibiotin-FITC for fluorescent microscopy. MFI, mean fluorescence intensity. CD45 is a plasma-membrane protein. For microscopy, nuclei were stained with DAPI. (a) and (b) right panels; quantification of repeat experiments $(n=2)$.

genic Hsp90 and its complexes from live cells by affinity capture, flow cytometry and microscopy.

Of all probes, we found only $\mathbf{2} \mathrm{g}$ to be very effective at both permeating cancer cell membranes and binding to and isolating Hsp90 onco-protein complexes from live cells (Figure 2a and d; red boxes), and its use is thus indicated for such applications. Probes $\mathbf{2 i}, \mathbf{2 f}$ and $\mathbf{2 h}$ remain of a yet uncharacterized category (Figure 2a and d; green boxes). Unlike probe $2 \mathbf{g}$, probes $\mathbf{2 i}$ and $\mathbf{2 h}$, and to some degree $\mathbf{2 f}$, failed to substantially degrade Raf-1 at concentrations as high as $20 \mu \mathrm{M}$ (Figure 2a). When incubated at such concentrations with live cells, a step followed by permeabilization of cells and complex capture on streptavidin beads, Hsp90 bound to Raf-1 was however isolated with these probes (Figure 2d). While apparently a paradoxical finding, one must note that $\mathbf{2 h}$ and $\mathbf{2 i}$ have in common the long 17-atom linker. It is possible that such compounds are prone to being trapped in the lipid bilayers of the plasma membrane, and thus, significant amounts become available for binding to intracellular Hsp90 only after the cell-permeabilization step (such as is performed in Figure 2d). Alternatively, it is plausible that these compounds get into the cell and become available for binding to the oncogenic Hsp90 complex in the live cell. The long chain however, characteristic of these probes, may interfere with 
recruitment of an E3 ligase to the Hsp90/onco-client complex, and proteasomal degradation of the client protein may be impeded as a result. We are conducting follow-up experiments to investigate such hypotheses; however, these studies are outside the scope of this manuscript.

In conclusion, our work identifies $\mathbf{2} \mathbf{g}$ as a probe for endogenous oncogenic Hsp90 and its protein clientele in live cells. The probe shows good affinity for tumor Hsp90 as demonstrated by FP, and good permeability as demonstrated by the two phenotypic read-outs of oncogenic Hsp90 inhibition (i.e., cytotoxicity and the ability to down regulate an Hsp90 onco-client protein in the relevant cancer cell background). $2 \mathrm{~g}$ can isolate Hsp90 through affinity purification from both cancer cell homogenates and live cells and is capable of trapping Hsp90 in an oncoclient-bound conformation facilitating the isolation of such complexes and their analysis and identification through classical biochemical techniques (i.e., Western blot). The probe, as we demonstrate here, is also of use in detecting and analyzing tumor Hsp90 by flow cytometry and microscopy. To our knowledge, $\mathbf{2} \mathbf{g}$ is the only reported biotinylated Hsp90 probe to have such combined characteristics, and thus represents a unique useful tool to investigate Hsp90 tumor biology.

\section{Experimental General}

${ }^{1} \mathrm{H}$ NMR spectra were recorded on a Bruker 500 or $600 \mathrm{MHz}$ instrument. Chemical shifts were reported in $\delta$ values in parts per million (ppm) downfield from TMS as the internal standard. ${ }^{1} \mathrm{H}$ data were reported as follows: chemical shift, multiplicity ( $\mathrm{s}=$ singlet, $\mathrm{d}=$ doublet, $\mathrm{t}=$ triplet, $\mathrm{q}=$ quartet, $\mathrm{br}=$ broad, $\mathrm{m}=$ multiplet), coupling constant $(\mathrm{Hz})$, integration. High-resolution mass spectra were recorded on a Waters LCT Premier system. Low-resolution mass spectra were obtained on a Waters Acquity Ultra Performance LC with electrospray ionization and SQ detector. High-performance liquid chromatography analyses were performed on a Waters Autopurification system with PDA, MicroMass ZQ, and ELSD detector, and a reversed-phase column (Waters X-Bridge C18, $4.6 \times 150 \mathrm{~mm}, 5 \mu \mathrm{m}$ ) using a gradient of (a) $\mathrm{H}_{2} \mathrm{O}+0.1 \%$ TFA and (b) $\mathrm{CH}_{3} \mathrm{CN}+0.1 \%$ TFA, 5 to $95 \%$ b over 13 minutes at $1.2 \mathrm{~mL} / \mathrm{min}$. All reactions were performed under argon protection. EZ-Link ${ }^{\circledR}$ NHS-LC-Biotin, EZ-Link ${ }^{\circledR}$ NHS-LC-LC-Biotin, EZ-Link ${ }^{\circledR}$ NHS-PEG $_{4}$-Biotin, and EZ-Link ${ }^{\circledR}$ Amine- $\mathrm{PEO}_{3}$-Biotin were purchased from Pierce (Rockford, Il). 1a [20], 1b [10] and biotinylated analogue 2a [9] were prepared as previously described.

\section{Synthesis of probes}

(2b). $1 \mathrm{a}$ (30 mg, $0.059 \mathrm{mmol})$, D-biotin (19 mg, $0.078 \mathrm{mmol})$, DCC (24 mg, $0.117 \mathrm{mmol}$ ) and a catalytic amount of DMAP in $\mathrm{CH}_{2} \mathrm{Cl}_{2}(1 \mathrm{~mL})$ were sonicated for $9 \mathrm{~h}$. The reaction mixture was concentrated under reduced pressure and the resulting residue was purified by preparative TLC $\left(\mathrm{CH}_{2} \mathrm{Cl}_{2} / \mathrm{MeOH}-\mathrm{NH}_{3}\right.$ (7 N), 10:1) to give $43.2 \mathrm{mg}$ (99\%) of $\mathbf{2 b} .{ }^{1} \mathrm{H}$ NMR (600 MHz, $\mathrm{CDCl}_{3}, 2$ rotamers) $\delta 8.22(\mathrm{~s}, 1 \mathrm{H}), 7.22(\mathrm{~s}, 0.6 \mathrm{H}), 7.21(\mathrm{~s}$, $0.4 \mathrm{H}), 6.87(\mathrm{~s}, 0.6 \mathrm{H}), 6.76(\mathrm{~s}, 0.4 \mathrm{H}), 6.25(\mathrm{br} \mathrm{s}, 0.6 \mathrm{H}), 6.16(\mathrm{br}$ $\mathrm{s}, 0.4 \mathrm{H}), 5.96-5.88(\mathrm{~m}, 2 \mathrm{H}), 5.85$ (br s, 0.6H), 5.78 (br s, 0.4H), $4.63-4.54(\mathrm{~m}, 0.6 \mathrm{H}), 4.45-4.32(\mathrm{~m}, 1.6 \mathrm{H}), 4.25-4.21(\mathrm{~m}, 0.4 \mathrm{H})$, $4.19-4.11(\mathrm{~m}, 1.4 \mathrm{H}), 4.07-4.00(\mathrm{~m}, 0.6 \mathrm{H}), 3.95-3.88(\mathrm{~m}, 0.4 \mathrm{H})$, $3.22-2.97(\mathrm{~m}, 2.4 \mathrm{H}), 2.84-2.78(\mathrm{~m}, 1 \mathrm{H}), 2.77-2.69(\mathrm{~m}, 0.6 \mathrm{H})$, $2.68-2.62(\mathrm{~m}, 1 \mathrm{H}), 2.27-2.22(\mathrm{~m}, 0.6 \mathrm{H}), 2.05-1.94(\mathrm{~m}, 1.4 \mathrm{H})$, $1.89-1.74(\mathrm{~m}, 1.4 \mathrm{H}), 1.72-1.43(\mathrm{~m}, 3 \mathrm{H}), 1.40-1.16(\mathrm{~m}, 3.6 \mathrm{H})$, $1.06-1.00(\mathrm{~m}, 4 \mathrm{H}), 0.97(\mathrm{~d}, J=6.7 \mathrm{~Hz}, 2 \mathrm{H})$; MS (ESI) $m / z$ : $739.2[\mathrm{M}+\mathrm{H}]^{+}$; HRMS-ESI $(\mathrm{m} / \mathrm{z}):[\mathrm{M}+\mathrm{H}]^{+}$calcd for $\mathrm{C}_{28} \mathrm{H}_{36} \mathrm{IN}_{8} \mathrm{O}_{4} \mathrm{~S}_{2}$, 739.1346; found, 739.1353; HPLC: $t_{\mathrm{R}}=9.83$.

(2c). 1 b $(9.1 \mathrm{mg}, 0.0193 \mathrm{mmol})$, D-biotin $(7.1 \mathrm{mg}$, $0.0290 \mathrm{mmol})$, DCC ( $8 \mathrm{mg}, 0.0386 \mathrm{mmol})$ and a catalytic amount of DMAP in $\mathrm{CH}_{2} \mathrm{Cl}_{2}(1 \mathrm{~mL})$ was sonicated for $5 \mathrm{~h}$. The reaction mixture was concentrated under reduced pressure and the resulting residue was purified by preparative TLC $\left(\mathrm{CH}_{2} \mathrm{Cl}_{2} /\right.$ $\left.\mathrm{MeOH}-\mathrm{NH}_{3}(7 \mathrm{~N}), 10: 1\right)$ to give $7.5 \mathrm{mg}(56 \%)$ of $2 \mathrm{c} .{ }^{1} \mathrm{H} \mathrm{NMR}$ $\left(600 \mathrm{MHz}, \mathrm{CDCl}_{3} / \mathrm{MeOH}-d_{4}\right) \delta 7.97(\mathrm{~s}, 1 \mathrm{H}), 7.17(\mathrm{~s}, 1 \mathrm{H}), 6.86$ (s, 1H), $5.84(\mathrm{~s}, 2 \mathrm{H}), 4.27-4.23(\mathrm{~m}, 1 \mathrm{H}), 4.09-4.05(\mathrm{~m}, 1 \mathrm{H})$, $4.03(\mathrm{t}, J=7.2 \mathrm{~Hz}, 2 \mathrm{H}), 3.02(\mathrm{t}, J=6.4 \mathrm{~Hz}, 2 \mathrm{H}), 2.97-2.90(\mathrm{~m}$, $1 \mathrm{H}), 2.67$ (dd, $J=4.9,12.8 \mathrm{~Hz}, 1 \mathrm{H}), 2.49$ (d, $J=12.8 \mathrm{~Hz}, 1 \mathrm{H})$, $2.01(\mathrm{t}, J=7.5 \mathrm{~Hz}, 2 \mathrm{H}), 1.83-1.75(\mathrm{~m}, 2 \mathrm{H}), 1.54-1.34(\mathrm{~m}, 4 \mathrm{H})$, 1.27-1.18 (m, 2H); MS (ESI) $m / z: 697.1[\mathrm{M}+\mathrm{H}]^{+}$; HRMS-ESI $(m / z):[\mathrm{M}+\mathrm{H}]^{+}$calcd for $\mathrm{C}_{25} \mathrm{H}_{30} \mathrm{IN}_{8} \mathrm{O}_{4} \mathrm{~S}_{2}, 697.0876$; found, 697.0904; HPLC: $t_{\mathrm{R}}=9.00$.

(2d). 1a $(15 \mathrm{mg}, 0.0292 \mathrm{mmol})$, EZ-Link ${ }^{\circledR}$ NHS-LC-Biotin $(14.6 \mathrm{mg}, 0.0321 \mathrm{mmol})$ and DIEA $(7.5 \mathrm{mg}, 10.2 \mu \mathrm{L}$, $0.0584 \mathrm{mmol})$ in DMF $(0.5 \mathrm{~mL})$ was heated at $35^{\circ} \mathrm{C}$ for $6 \mathrm{~h}$. The reaction mixture was concentrated under reduced pressure and the resulting residue was purified by preparative TLC $\left(\mathrm{CH}_{2} \mathrm{Cl}_{2} / \mathrm{MeOH}-\mathrm{NH}_{3}(7 \mathrm{~N}), 10: 1\right)$ to give $10.3 \mathrm{mg}$ (41\%) of $\mathbf{2 d}$. In addition, $6.9 \mathrm{mg}$ of unreacted $1 \mathrm{a}$ was recovered to give an actual yield of $77 \%$. ${ }^{1} \mathrm{H}$ NMR ( $500 \mathrm{MHz}, \mathrm{CDCl}_{3}, 2$ rotamers) $\delta$ 8.29-8.26 (m, 1H), 7.29 (s, 0.4H), $7.28(\mathrm{~s}, 0.6 \mathrm{H}), 6.87(\mathrm{~s}, 0.4 \mathrm{H})$, $6.85(\mathrm{~s}, 0.6 \mathrm{H}), 6.76(\mathrm{br} \mathrm{s}, 0.4 \mathrm{H}), 6.74(\mathrm{br} \mathrm{s}, 0.6 \mathrm{H}), 6.63-6.51(\mathrm{br}$ $\mathrm{s}, 2 \mathrm{H}), 6.00-5.96(\mathrm{~m}, 2 \mathrm{H}), 5.68(\mathrm{br} \mathrm{s}, 0.4 \mathrm{H}), 5.58(\mathrm{br} \mathrm{s}, 0.6 \mathrm{H})$, $4.64-4.56(\mathrm{~m}, 0.4 \mathrm{H}), 4.52-4.45(\mathrm{~m}, 1 \mathrm{H}), 4.36-4.28(\mathrm{~m}, 1 \mathrm{H})$, $4.27-4.20(\mathrm{~m}, 2 \mathrm{H}), 4.09-4.01(\mathrm{~m}, 0.6 \mathrm{H}), 3.32-3.08(\mathrm{~m}, 5 \mathrm{H})$, 2.94-2.86 (m, 1H), 2.76-2.69 (m, 1H), 2.37-2.31 (m, 1H), $2.22-1.96(\mathrm{~m}, 4 \mathrm{H}), 1.96-1.89(\mathrm{~m}, 1 \mathrm{H}), 1.80-1.30(\mathrm{~m}, 12 \mathrm{H})$, 1.16-1.10 (m, 4H), 1.09-1.04 (m, 2H); MS (ESI) $m / z: 852.3[\mathrm{M}$ $+\mathrm{H}]^{+}$; HRMS-ESI $(m / z):[\mathrm{M}+\mathrm{H}]^{+}$calcd for $\mathrm{C}_{34} \mathrm{H}_{47} \mathrm{IN}_{9} \mathrm{O}_{5} \mathrm{~S}_{2}$, 852.2186; found, 852.2206; HPLC: $t_{\mathrm{R}}=8.82$.

(2e). 1b (16.9 mg, 0.0359 mmol), EZ-Link ${ }^{\circledR}$ NHS-LC-Biotin (17.9 mg, $0.0394 \mathrm{mmol})$ and DIEA $(9.3 \mathrm{mg}, 12.5 \mu \mathrm{L}$, 
$0.0718 \mathrm{mmol})$ in DMF $(0.5 \mathrm{~mL})$ was stirred at $\mathrm{rt}$ for $1 \mathrm{~h}$. The reaction mixture was concentrated under reduced pressure and the resulting residue was purified by preparative TLC $\left(\mathrm{CH}_{2} \mathrm{Cl}_{2} /\right.$ MeOH-NH $3(7 \mathrm{~N}), 10: 1)$ to give $20.8 \mathrm{mg}(72 \%)$ of 2 e. ${ }^{1} \mathrm{H}$ NMR $\left(500 \mathrm{MHz}, \mathrm{CDCl}_{3}\right) \delta 8.22(\mathrm{~s}, 1 \mathrm{H}), 7.52(\mathrm{t}, J=5.6 \mathrm{~Hz}, 1 \mathrm{H}), 7.36$ (s, 1H), $7.03(\mathrm{~s}, 1 \mathrm{H}), 6.66(\mathrm{t}, J=5.5 \mathrm{~Hz}, 1 \mathrm{H}), 6.25$ (br s, $2 \mathrm{H})$, $6.03(\mathrm{~s}, 2 \mathrm{H}), 4.52-4.47(\mathrm{~m}, 1 \mathrm{H}), 4.33-4.28(\mathrm{~m}, 1 \mathrm{H}), 4.25(\mathrm{t}, J=$ $6.8 \mathrm{~Hz}, 2 \mathrm{H}), 3.25-3.17(\mathrm{~m}, 4 \mathrm{H}), 3.17-3.11(\mathrm{~m}, 1 \mathrm{H}), 2.90(\mathrm{dd}, J$ $=5.0,12.9 \mathrm{~Hz}, 1 \mathrm{H}), 2.79-2.63(\mathrm{~m}, 1 \mathrm{H}), 2.24(\mathrm{t}, J=7.4 \mathrm{~Hz}$, $2 \mathrm{H}), 2.19-2.13(\mathrm{~m}, 2 \mathrm{H}), 2.02-1.94(\mathrm{~m}, 2 \mathrm{H}), 1.74-1.58(\mathrm{~m}, 6 \mathrm{H})$, $1.56-1.48$ (m, 2H), 1.46-1.31 (m, 4H); MS (ESI) $m / z: 810.3[\mathrm{M}$ $+\mathrm{H}]^{+}$; HRMS-ESI $(m / z):[\mathrm{M}+\mathrm{H}]^{+}$calcd for $\mathrm{C}_{31} \mathrm{H}_{41} \mathrm{IN}_{9} \mathrm{O}_{5} \mathrm{~S}_{2}$, 810.1717; found, 810.1703; HPLC: $t_{\mathrm{R}}=8.00$.

(2f). 1a (15 mg, $0.0292 \mathrm{mmol})$, EZ-Link ${ }^{\circledR}$ NHS-LC-LC-Biotin $(18.2 \mathrm{mg}, 0.0321 \mathrm{mmol})$ and DIEA $(7.5 \mathrm{mg}, 10.2 \mu \mathrm{L}$, $0.0584 \mathrm{mmol})$ in DMF $(0.5 \mathrm{~mL})$ was heated at $35^{\circ} \mathrm{C}$ for $6 \mathrm{~h}$. The reaction mixture was concentrated under reduced pressure and the resulting residue was purified by preparatory TLC $\left(\mathrm{CH}_{2} \mathrm{Cl}_{2} / \mathrm{MeOH}-\mathrm{NH}_{3}(7 \mathrm{~N}), 10: 1\right)$ to give $8.2 \mathrm{mg}(29 \%)$ of $\mathbf{2 f}$. In addition, $9.6 \mathrm{mg}$ of unreacted $\mathbf{1 a}$ was recovered to give an actual yield of $81 \%$. ${ }^{1} \mathrm{H}$ NMR $\left(500 \mathrm{MHz}, \mathrm{CDCl}_{3} / \mathrm{MeOH}-d_{4}, 2\right.$ rotamers) $\delta 8.18(\mathrm{~s}, 0.4 \mathrm{H}), 8.16(\mathrm{~s}, 0.6 \mathrm{H}), 7.31(\mathrm{~s}, 1 \mathrm{H}), 6.98(\mathrm{~s}$, $0.6 \mathrm{H}), 6.95(\mathrm{~s}, 0.4 \mathrm{H}), 6.90-6.80(\mathrm{~m}, 2 \mathrm{H}), 5.98(\mathrm{~s}, 2 \mathrm{H})$, 4.55-4.47 (m, 0.4H), 4.47-4.41 (m, 1H), 4.27-4.23 (m, 1H), $4.22-4.16(\mathrm{~m}, 2 \mathrm{H}), 4.03-3.95(\mathrm{~m}, 0.6 \mathrm{H}), 3.34-3.31(\mathrm{~m}, 0.6 \mathrm{H})$, 3.24-3.19 (m, 1.4H), 3.17-3.07 (m, 5H), 2.89-2.82 (m, 1H), 2.70-2.64 (m, 1H), 2.32-2.25 (m, 1H), 2.16-1.94 (m, 7H), $1.70-1.18(\mathrm{~m}, 18 \mathrm{H}), 1.09$ (d, $J=6.7 \mathrm{~Hz}, 4 \mathrm{H}), 1.03$ (d, $J=6.8$ $\mathrm{Hz}, 2 \mathrm{H})$; MS (ESI) $m / z$ : $965.5[\mathrm{M}+\mathrm{H}]^{+}$; HRMS-ESI $(\mathrm{m} / \mathrm{z})$ : [M $+\mathrm{H}]^{+}$calcd. for $\mathrm{C}_{40} \mathrm{H}_{58} \mathrm{IN}_{10} \mathrm{O}_{6} \mathrm{~S}_{2}$, 965.3027; found, 965.3010; HPLC: $t_{\mathrm{R}}=8.73$.

(2g). 1b (16.6 mg, 0.0352 mmol), EZ-Link ${ }^{\circledR}$ NHS-LC-LCBiotin (22.0 mg, $0.0387 \mathrm{mmol})$ and DIEA $(9.1 \mathrm{mg}, 12.3 \mu \mathrm{L}$, $0.0704 \mathrm{mmol})$ in DMF $(0.5 \mathrm{~mL})$ was stirred at $\mathrm{rt}$ for $1 \mathrm{~h}$. The reaction mixture was concentrated under reduced pressure and the resulting residue was purified by preparative TLC $\left(\mathrm{CH}_{2} \mathrm{Cl}_{2} /\right.$ $\left.\mathrm{MeOH}-\mathrm{NH}_{3}(7 \mathrm{~N}), 10: 1\right)$ to give $27.8 \mathrm{mg}(86 \%)$ of $\mathbf{2 g} .{ }^{1} \mathrm{H} \mathrm{NMR}$ $\left(500 \mathrm{MHz}, \mathrm{CDCl}_{3} / \mathrm{MeOH}-d_{4}\right) \delta 8.12(\mathrm{~s}, 1 \mathrm{H}), 7.60(\mathrm{~m}, 1 \mathrm{H}), 7.30$ $(\mathrm{s}, 1 \mathrm{H}), 7.09(\mathrm{~m}, 1 \mathrm{H}), 6.98(\mathrm{~s}, 1 \mathrm{H}), 5.97(\mathrm{~s}, 2 \mathrm{H}), 4.44-4.38(\mathrm{~m}$, $1 \mathrm{H}), 4.24-4.20(\mathrm{~m}, 1 \mathrm{H}), 4.17(\mathrm{t}, J=7.1 \mathrm{~Hz}, 2 \mathrm{H}), 3.18-3.04(\mathrm{~m}$, $7 \mathrm{H}), 2.83(\mathrm{dd}, J=5.0,12.9 \mathrm{~Hz}, 1 \mathrm{H}), 2.64(\mathrm{~d}, J=12.8 \mathrm{~Hz}, 1 \mathrm{H})$, $2.16(\mathrm{t}, J=7.5 \mathrm{~Hz}, 2 \mathrm{H}), 2.12-2.03(\mathrm{~m}, 4 \mathrm{H}), 1.96-1.88(\mathrm{~m}, 2 \mathrm{H})$, $1.66-1.18(\mathrm{~m}, 18 \mathrm{H})$; MS (ESI) $m / z: 923.4[\mathrm{M}+\mathrm{H}]^{+}$; HRMS-ESI $(m / z):[\mathrm{M}+\mathrm{H}]^{+}$calcd for $\mathrm{C}_{37} \mathrm{H}_{52} \mathrm{IN}_{10} \mathrm{O}_{6} \mathrm{~S}_{2}$, 923.2558; found, 923.2595; HPLC: $t_{\mathrm{R}}=7.95$.

(2h). 1a (15 mg, 0.0292 mmol), EZ-Link ${ }^{\circledR}$ NHS-PEG $_{4}$-Biotin $(18.9 \mathrm{mg}, 0.0321 \mathrm{mmol})$ and DIEA $(7.5 \mathrm{mg}, 10.2 \mu \mathrm{L}$, $0.0584 \mathrm{mmol})$ in DMF $(0.5 \mathrm{~mL})$ was heated at $35^{\circ} \mathrm{C}$ for $6 \mathrm{~h}$.
The reaction mixture was concentrated under reduced pressure, and the resulting residue was purified by preparatory TLC $\left(\mathrm{CH}_{2} \mathrm{Cl}_{2} / \mathrm{MeOH}-\mathrm{NH}_{3}(7 \mathrm{~N}), 10: 1\right)$ to give $9.3 \mathrm{mg}(32 \%)$ of $\mathbf{2 h}$. In addition, $9.0 \mathrm{mg}$ of unreacted $\mathbf{1 a}$ was recovered to give an actual yield of $81 \%$. ${ }^{1} \mathrm{H}$ NMR $\left(500 \mathrm{MHz}, \mathrm{CDCl}_{3} / \mathrm{MeOH}-d_{4}, 2\right.$ rotamers) $\delta 8.18(\mathrm{~s}, 0.4 \mathrm{H}), 8.16(\mathrm{~s}, 0.6 \mathrm{H}), 7.32-7.30(\mathrm{~m}, 1 \mathrm{H})$, $6.98(\mathrm{~s}, 0.6 \mathrm{H}), 6.96(\mathrm{~s}, 0.4 \mathrm{H}), 5.98(\mathrm{~s}, 2 \mathrm{H}), 4.56-4.49(\mathrm{~m}, 0.4 \mathrm{H})$, 4.46-4.39 (m, 1H), 4.27-4.22 (m, 1H), 4.21-4.15 (m, 2H), $4.07-3.99(\mathrm{~m}, 0.6 \mathrm{H}), 3.71-3.66(\mathrm{~m}, 2 \mathrm{H}), 3.61-3.51(\mathrm{~m}, 12 \mathrm{H})$, $3.50-3.45(\mathrm{~m}, 2 \mathrm{H}), 3.38-3.29(\mathrm{~m}, 2 \mathrm{H}), 3.25-3.16(\mathrm{~m}, 2 \mathrm{H})$, $3.12-3.07(\mathrm{~m}, 1 \mathrm{H}), 2.88-2.81(\mathrm{~m}, 1 \mathrm{H}), 2.68-2.63(\mathrm{~m}, 1 \mathrm{H})$, $2.63-2.57(\mathrm{~m}, 1.2 \mathrm{H}), 2.47-2.41(\mathrm{~m}, 0.8 \mathrm{H}), 2.18-1.98(\mathrm{~m}, 4 \mathrm{H})$, $1.70-1.52(\mathrm{~m}, 4 \mathrm{H}), 1.41-1.32(\mathrm{~m}, 2 \mathrm{H}), 1.08(\mathrm{~d}, J=6.7 \mathrm{~Hz}, 4 \mathrm{H})$, $1.02(\mathrm{~d}, J=6.8 \mathrm{~Hz}, 2 \mathrm{H})$; MS (ESI) $m / z: 986.5[\mathrm{M}+\mathrm{H}]^{+}$; HRMS-ESI $(m / z):[\mathrm{M}+\mathrm{H}]^{+}$calcd for $\mathrm{C}_{39} \mathrm{H}_{57} \mathrm{IN}_{9} \mathrm{O}_{9} \mathrm{~S}_{2}$, 986.2765; found, 986.2757; HPLC: $t_{\mathrm{R}}=8.53$.

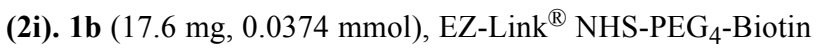
(24.2 $\mathrm{mg}, 0.0411 \mathrm{mmol})$ and DIEA $(9.7 \mathrm{mg}, 13 \mu \mathrm{L}$, $0.0704 \mathrm{mmol})$ in DMF $(0.5 \mathrm{~mL})$ was stirred at $\mathrm{rt}$ for $1 \mathrm{~h}$. The reaction mixture was concentrated under reduced pressure and the resulting residue was purified by preparative TLC $\left(\mathrm{CH}_{2} \mathrm{Cl}_{2} /\right.$ $\left.\mathrm{MeOH}-\mathrm{NH}_{3}(7 \mathrm{~N}), 10: 1\right)$ to give $31.0 \mathrm{mg}(88 \%)$ of $\mathbf{2 i} .{ }^{1} \mathrm{H}$ NMR $\left(500 \mathrm{MHz}, \mathrm{CDCl}_{3}\right) \delta 8.29(\mathrm{~s}, 1 \mathrm{H}), 7.51(\mathrm{t}, J=5.8 \mathrm{~Hz}, 1 \mathrm{H}), 7.32$ $(\mathrm{s}, 1 \mathrm{H}), 7.03(\mathrm{t}, J=5.3 \mathrm{~Hz}, 1 \mathrm{H}), 6.90(\mathrm{~s}, 1 \mathrm{H}), 6.79(\mathrm{~s}, 1 \mathrm{H}), 6.57$ (br s, 2H), $6.01(\mathrm{~s}, 2 \mathrm{H}), 5.97(\mathrm{~s}, 1 \mathrm{H}), 4.53-4.48(\mathrm{~m}, 1 \mathrm{H})$, 4.35-4.25 (m, 3H), $3.79(\mathrm{t}, J=6.1 \mathrm{~Hz}, 2 \mathrm{H}), 3.68-3.59(\mathrm{~m}$, $12 \mathrm{H}), 3.57(\mathrm{t}, J=5.1 \mathrm{~Hz}, 2 \mathrm{H}), 3.46-3.40(\mathrm{~m}, 2 \mathrm{H}), 3.24-3.18$ $(\mathrm{m}, 2 \mathrm{H}), 3.18-3.12(\mathrm{~m}, 1 \mathrm{H}), 2.90(\mathrm{dd}, J=5.0,12.8 \mathrm{~Hz}, 1 \mathrm{H})$, $2.75(\mathrm{~d}, J=12.7 \mathrm{~Hz}, 1 \mathrm{H}), 2.54(\mathrm{t}, J=6.0 \mathrm{~Hz}, 2 \mathrm{H}), 2.20(\mathrm{t}, J=$ $7.4 \mathrm{~Hz}, 2 \mathrm{H}), 2.01-1.40(\mathrm{~m}, 2 \mathrm{H}), 1.79-1.59$ (m, 4H), 1.48-1.38 (m, 2H); MS (ESI) $m / z$ : $944.4[\mathrm{M}+\mathrm{H}]^{+}$; HRMS-ESI $(m / z)$ : [M $+\mathrm{H}]^{+}$calcd for $\mathrm{C}_{36} \mathrm{H}_{51} \mathrm{IN}_{9} \mathrm{O}_{9} \mathrm{~S}_{2}, 944.2296$; found, 944.2307; HPLC: $t_{\mathrm{R}}=7.82$.

\section{6-Amino- $N$-(3-(6-amino-8-(6-iodobenzo[d] $[1,3]$ dioxol-5-} ylthio)-9H-purin-9-yl)propyl)- $\boldsymbol{N}$-isopropylhexanamide (3). 1a (50 mg, $0.0975 \mathrm{mmol}), 6$-Boc-aminocaproic acid (29 mg, $0.127 \mathrm{mmol})$, DCC (40.2 $\mathrm{mg}, 0.195 \mathrm{mmol})$ and a catalytic amount of DMAP in $\mathrm{CH}_{2} \mathrm{Cl}_{2}(1.5 \mathrm{~mL})$ was stirred at $\mathrm{rt}$ overnight. The reaction mixture was concentrated under reduced pressure, and the resulting residue was partially purified by preparative TLC $\left(\mathrm{CH}_{2} \mathrm{Cl}_{2} / \mathrm{MeOH}-\mathrm{NH}_{3}(7 \mathrm{~N}), 12: 1\right)$ to give a residue, which was dissolved in TFA/ $\mathrm{CH}_{2} \mathrm{Cl}_{2}$ (0.4:1.6 mL) and stirred for $20 \mathrm{~min}$ at $\mathrm{rt}$. The reaction mixture was concentrated under reduced pressure and the resulting residue was purified by preparative TLC $\left(\mathrm{CH}_{2} \mathrm{Cl}_{2} / \mathrm{MeOH}-\mathrm{NH}_{3}\right.$ $(7 \mathrm{~N}), 10: 1)$ to give $55 \mathrm{mg}$ (90\%) of $3 .{ }^{1} \mathrm{H} \mathrm{NMR}(500 \mathrm{MHz}$, $\mathrm{CDCl}_{3}, 2$ rotamers) $\delta 8.38-8.34(\mathrm{~m}, 1 \mathrm{H}), 7.35(\mathrm{~s}, 0.4 \mathrm{H}), 7.33(\mathrm{~s}$, $0.6 \mathrm{H}), 6.98(\mathrm{~s}, 0.4 \mathrm{H}), 6.93(\mathrm{~s}, 0.6 \mathrm{H}), 6.05-6.01(\mathrm{~m}, 2 \mathrm{H}), 5.72$ (br s, 2H), 4.69-4.63 (m, 0.4H), $4.29(\mathrm{t}, J=7.2 \mathrm{~Hz}, 2 \mathrm{H})$, 
4.10-4.02 (m, 0.6H), 3.31-3.25 (m, 1.2H), 3.20-3.14 (m, 0.8H), 2.80-2.70 (m, 2H), $2.37(\mathrm{t}, J=7.5 \mathrm{~Hz}, 1.2 \mathrm{H}), 2.15-2.06(\mathrm{~m}$, $2 \mathrm{H}), 2.01-1.89(\mathrm{~m}, 0.8 \mathrm{H}), 1.70-1.62(\mathrm{~m}, 1.2 \mathrm{H}), 1.58-1.48(\mathrm{~m}$, $2 \mathrm{H}), 1.45-1.36(\mathrm{~m}, 2 \mathrm{H}), 1.24-1.16(\mathrm{~m}, 0.8 \mathrm{H}), 1.14(\mathrm{~d}, J=6.7$ $\mathrm{Hz}, 3.6 \mathrm{H}), 1.09$ (d, $J=6.9 \mathrm{~Hz}, 2.4 \mathrm{H})$; MS (ESI) $m / z: 626.2[\mathrm{M}$ $+\mathrm{H}]^{+}$; HRMS-ESI $(m / z):[\mathrm{M}+\mathrm{H}]^{+}$calcd for $\mathrm{C}_{24} \mathrm{H}_{33} \mathrm{IN}_{7} \mathrm{O}_{3} \mathrm{~S}$, 626.1410; found, 626.1411; HPLC: $t_{\mathrm{R}}=7.92$.

(2d). $3(50 \mathrm{mg}, 0.0798 \mathrm{mmol})$, D-biotin (25.3 mg, $0.1037 \mathrm{mmol}), \mathrm{DCC}(32.9 \mathrm{mg}, 0.1596 \mathrm{mmol})$ and a catalytic amount of DMAP in $\mathrm{CH}_{2} \mathrm{Cl}_{2}(2 \mathrm{~mL})$ was sonicated for $6 \mathrm{~h}$. The reaction mixture was concentrated under reduced pressure and the resulting residue was purified by preparative TLC $\left(\mathrm{CH}_{2} \mathrm{Cl}_{2} /\right.$ $\left.\mathrm{MeOH}-\mathrm{NH}_{3}(7 \mathrm{~N}), 10: 1\right)$ to give $31.9 \mathrm{mg}(47 \%)$ of $\mathbf{2 d}$. MS (ESI) $m / z: 852.3[\mathrm{M}+\mathrm{H}]^{+}$; HPLC: $t_{\mathrm{R}}=8.82$.

\section{Biological evaluation of probes}

Hsp90 competition assay. For the competition studies, fluorescence polarization (FP) assays were performed as previously reported [9,23]. Briefly, FP measurements were performed on an Analyst GT instrument (Molecular Devices, Sunnyvale, CA). Measurements were taken in black 96-well microtiter plates (Corning \# 3650) where both the excitation and the emission occurred from the top of the wells. A stock of $10 \mu \mathrm{M}$ GM-cy3B was prepared in DMSO and diluted with Felts buffer $(20 \mathrm{mM}$ Hepes (K), pH 7.3, $50 \mathrm{mM} \mathrm{KCl,} 2 \mathrm{mM}$ DTT, $5 \mathrm{mM} \mathrm{MgCl}_{2}$,

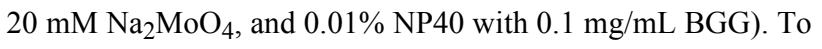
each 96-well were added $6 \mathrm{nM}$ fluorescent GM (GM-cy3B), $3 \mu \mathrm{g}$ SKBr3 lysate (total protein), and test compound (initial stock in DMSO) in a final volume of $100 \mu \mathrm{L}$ Felts buffer. Compounds were added in triplicate wells. For each assay, background wells (buffer only), tracer controls (free, fluorescent GM only) and bound GM controls (fluorescent GM in the presence of SKBr3 lysate) were included on each assay plate. GM was used as positive control. The assay plate was incubated on a shaker at $4{ }^{\circ} \mathrm{C}$ for $24 \mathrm{~h}$ and the FP values in $\mathrm{mP}$ were measured. The fraction of tracer bound to Hsp90 was correlated to the $\mathrm{mP}$ value and plotted against values of competitor concentrations. The inhibitor concentration at which $50 \%$ of bound GM was displaced was obtained by fitting the data. All experimental data were analyzed using SOFTmax Pro 4.3.1 and plotted using Prism 4.0 (Graphpad Software Inc., San Diego, CA).

Western blotting. The K562 cell line was purchased from the American Type Culture Collection (Manassas, VA) and cultured in Roswell Park Memorial Institute (RPMI) supplemented with $10 \%$ fetal bovine serum, $1 \%$ L-glutamine, $1 \%$ penicillin and streptomycin. Cells were plated for $24 \mathrm{~h}$ prior to treatment for the indicated times with DMSO (vehicle) or with the indicated compounds. Protein extracts were prepared in
$50 \mathrm{mM}$ Tris $\mathrm{pH} 7.4,150 \mathrm{mM} \mathrm{NaCl}$ and 1\% NP-40 lysis buffer. Protein concentrations were measured by using the BCA kit (Pierce) according to the manufacturer's instructions. Protein lysates $(50 \mu \mathrm{g})$ were resolved by SDS-PAGE, transferred onto nitrocellulose membrane and incubated with an anti-Raf-1 antibody from rabbit (1:500, sc-133, Santa Cruz) or anti- $\beta$-actin from mouse (1:2,500, A1978, Sigma-Aldrich). Membranes were then incubated with the corresponding peroxidase-conjugated secondary antibody (1:3,000 dilution) and visualized by the ECL detection reagent (Amersham).

Chemical precipitation from cells. K562 cells were treated with the indicated compounds for $4 \mathrm{~h}$, after which cells were collected and washed three times with PBS. Protein extracts were prepared by sonicating cells in $20 \mathrm{mM}$ HEPES, $\mathrm{pH} 7.3$, $50 \mathrm{mM} \mathrm{KCl}, 5 \mathrm{mM} \mathrm{MgCl}_{2}, 20 \mathrm{mM} \mathrm{Na}_{2} \mathrm{MoO}_{4}, 0.01 \% \mathrm{NP} 40$ lysis buffer. Streptavidin agarose beads $(40 \mu \mathrm{L})$ (Thermo Scientific) were washed three times with the lysis buffer and added to $500 \mu \mathrm{g}$ of the total cellular protein extract diluted in lysis buffer to a final volume of $120 \mu \mathrm{L}$. Samples were incubated at $4{ }^{\circ} \mathrm{C}$ for $1 \mathrm{~h}$, washed five times with the lysis buffer (or high salt buffer containing $1 \mathrm{M} \mathrm{NaCl}$ added to the lysis buffer) and applied to SDS-PAGE. Gels were stained with Coomassie blue (BioRad) according to the manufacturer's instructions.

Competitive binding. K562 cells were pretreated with PU-H71 $(5 \mu \mathrm{M})$ for $30 \mathrm{~min}$, followed by treatment for $4 \mathrm{~h}$ with the indicated biotinylated probe $(5 \mu \mathrm{M})$. Cells were washed three times with PBS and sonicated in Felts buffer. Protein $(500 \mu \mathrm{g})$ was added to streptavidin beads, and samples were incubated for $1 \mathrm{~h}$ at $4{ }^{\circ} \mathrm{C}$. Affinity-purified protein was washed and then applied to SDS-PAGE.

Chemical precipitation from cell lysates. K562 cells were sonicated in $20 \mathrm{mM}$ HEPES, $\mathrm{pH} 7.3,50 \mathrm{mM} \mathrm{KCl}, 5 \mathrm{mM}$ $\mathrm{MgCl}_{2}, 20 \mathrm{mM} \mathrm{Na} \mathrm{MoO}_{4}$, and $0.01 \% \mathrm{NP} 40$ lysis buffer containing added protease inhibitors. Affinity beads were prepared by addition of the biotinylated probes to the streptavidin agarose resin $(40 \mu \mathrm{L})$ (Thermo Scientific), which was first washed three times with the lysis buffer. Following incubation at $4{ }^{\circ} \mathrm{C}$ for $1 \mathrm{~h}$, the obtained Hsp90 affinity beads were washed three times with lysis buffer to remove any unbound materials. The protein extract $(500 \mu \mathrm{g})$ was then added to the probe-bound beads, and samples were incubated at $4{ }^{\circ} \mathrm{C}$ overnight. Following five washes with lysis buffer, the protein isolates were subjected to SDS-PAGE.

Growth inhibition assay. The effect of compounds on cell growth was evaluated with the Alamar Blue assay [26]. In summary, K562 cells were plated at 20,000 cells/well on Costar 96-well plates. Treatment with the probes added at the indi- 
cated concentrations in triplicate wells was performed on the subsequent day and lasted for $72 \mathrm{~h}$. The Alamar Blue reagent resazurin ( $440 \mu \mathrm{M}$ stock) was added at the end of the treatment to result in a final concentration of $50 \mu \mathrm{M}$. Plates were read $6 \mathrm{~h}$ later by using the Analyst GT instrument (Fluorescence intensity mode, excitation $530 \mathrm{~nm}$, emission $580 \mathrm{~nm}$, with $560 \mathrm{~nm}$ dichroic mirror). Results were analyzed in SoftMax Pro. The percentage of cell growth inhibition was calculated by comparing fluorescence readings obtained from treated versus control cells, accounting for the initial cell population (time zero). The $\mathrm{IC}_{50}$ was calculated as the drug concentration that inhibits cell growth by $50 \%$.

Flow cytometry analysis. Live cells. K562 cells were pretreated for $4 \mathrm{~h}$ with the indicated biotinylated probe, washed and stained on ice with CD45-Allophycocyanin (APC) (eBioscience) in PBS $/ 5 \%$ FBS for 30 min. Cells were then washed and stained on ice with $0.125 \mu \mathrm{g}$ of Anti-Biotin-PE in PBS $/ 5 \%$ FBS for $45 \mathrm{~min}$, followed by 4',6-diamidino-2-phenylindole (DAPI) $(1 \mu \mathrm{g} / \mathrm{mL})$ staining. Mean fluorescence intensity (MFI) of phycoerythrin (PE) was determined in DAPI negative viable cells. Digitonin permeabilized cells. K562 cells were pretreated for $4 \mathrm{~h}$ with the indicated biotinylated probes, washed and stained on ice with CD45-APC in PBS/5\% FBS for $30 \mathrm{~min}$. CD45 is expressed on the cell surface of all hematopoietic cells excluding mature erythrocytes and platelets. Cells were then fixed for $30 \mathrm{~min}$ with Cytofix buffer (BD Biosciences), washed and permeabilized with digitonin $(10 \mu \mathrm{g} / \mathrm{mL})$, followed by washing and staining with $0.125 \mu \mathrm{g}$ of anti-Biotin-PE in the presence of digitonin for $30 \mathrm{~min}$. Cells were then stained with DAPI $(1 \mu \mathrm{g} / \mathrm{mL})$. Cells were washed and then analyzed by flow cytometry (LSR-II, BD Biosciences).

Fluorescence microscopy. K562 cells were treated with $10 \mu \mathrm{M}$ 2g or DMSO (control) at $37{ }^{\circ} \mathrm{C}$ for $4 \mathrm{~h}$. Cells were then collected, washed twice with PBS and attached to a chamber slide by centrifugation at $1,000 \mathrm{rpm}$ at $4{ }^{\circ} \mathrm{C}$ for $5 \mathrm{~min}$. Cells were then fixed with $4 \%$ paraformaldehyde in PBS at room temperature for $15 \mathrm{~min}$ and then washed twice with PBS. Cells were permeabilized with $50 \mu \mathrm{g} / \mu \mathrm{L}$ digitonin (Gold Biotechnology special grade Cat\# D-180-250) in PBS at room temperature for $15 \mathrm{~min}$. Cells were washed twice with PBS and incubated in 10\% BSA in PBS at room temperature for $1.5 \mathrm{~h}$. Cells were then washed twice with PBS and incubated with AntiBiotin-FITC antibody (Sigma cat\# F6762), diluted 1:50 in PBS, at room temperature for $1 \mathrm{~h}$. Cells were then washed twice with PBS and stained with DAPI in ProLong Gold anti-fade reagent (Life Technologies cat\# P36935) at which point a cover slip was attached to the chamber slide. Slides were visualized using a Leica SP5 Upright point-scanning confocal microscope at an objective of $40 \times$ oil $(x=2048, y=2048, z=1)$.

\section{Acknowledgements}

G.C. is funded by Leukemia and Lymphoma Society, Breast Cancer Research Fund, W.H. Goodwin and A. Goodwin and the Commonwealth Cancer Foundation for Research, The Experimental Therapeutics Center of Memorial Sloan-Kettering Cancer Center (MSKCC), 1U01 AG032969-01A1, 1R21 CA158609-01A1, 1R21 AI090501 and 1R01 CA155226-01. T.T. is funded by Susan G. Komen for the Cure (KG091313) and the Department of Defense, Breast Cancer Research Program (PDF-BC093421). We also thank Dr. George Sukenick and Dr. Hui Liu of the NMR Analytical Core Facility at MSKCC for expert mass spectral analysis.

\section{References}

1. Taipale, M.; Jarosz, D. F.; Lindquist, S. Nat. Rev. Mol. Cell Biol. 2010, 11, 515-528. doi:10.1038/nrm2918

2. Workman, P.; Burrows, F.; Neckers, L.; Rosen, N. Ann. N. Y. Acad. Sci. 2007, 1113, 202-216. doi:10.1196/annals.1391.012

3. Janin, Y. L. Drug Discovery Today 2010, 15, 342-353. doi:10.1016/j.drudis.2010.03.002

4. Jhaveri, K.; Taldone, T.; Modi, S.; Chiosis, G. Biochim. Biophys. Acta 2012, 1823, 742-755. doi:10.1016/j.bbamcr.2011.10.008

5. Patel, H. J.; Modi, S.; Chiosis, G.; Taldone, T. Expert Opin. Drug Discovery 2011, 6, 559-587. doi:10.1517/17460441.2011.563296

6. Chène, P. Nat. Rev. Drug Discovery 2002, 1, 665-673. doi:10.1038/nrd894

7. Porter, J. R.; Fritz, C. C.; Depew, K. M. Curr. Opin. Chem. Biol. 2010, 14, 412-420. doi:10.1016/j.cbpa.2010.03.019

8. Donnelly, A.; Blagg, B. S. J. Curr. Med. Chem. 2008, 15, 2702-2717. doi:10.2174/092986708786242895

9. Taldone, T.; Zatorska, D.; Patel, P. D.; Zong, H.; Rodina, A.; Ahn, J. H.; Moulick, K.; Guzman, M. L.; Chiosis, G. Bioorg. Med. Chem. 2011, 19, 2603-2614. doi:10.1016/j.bmc.2011.03.013

10. Taldone, T.; Gomes-DaGama, E. M.; Zong, H.; Sen, S.; Alpaugh, M. L.; Zatorska, D.; Alonso-Sabadell, R.; Guzman, M. L.; Chiosis, G. Bioorg. Med. Chem. Lett. 2011, 21, 5347-5352. doi:10.1016/j.bmcl.2011.07.026

11. Hughes, P. F.; Barrott, J. J.; Carlson, D. A.; Loiselle, D. R.; Speer, B. L.; Bodoor, K.; Rund, L. A.; Haystead, T. A. J. Bioorg. Med. Chem. 2012, 20, 3298-3305. doi:10.1016/j.bmc.2012.03.043

12. Taldone, T.; Chiosis, G. Curr. Top. Med. Chem. 2009, 9, 1436-1446. doi:10.2174/156802609789895737

13. Moulick, K.; Ahn, J. H.; Zong, H.; Rodina, A.; Cerchietti, L.; Gomes-DaGama, E. M.; Caldas-Lopes, E.; Beebe, K.; Perna, F.; Hatzi, K.; Vu, L. P.; Zhao, X.; Zatorska, D.; Taldone, T.; Smith-Jones, P.; Alpaugh, M.; Gross, S. S.; Pillarsetty, N.; Ku, T.; Lewis, J. S.; Larson, S. M.; Levine, R.; Erdjument-Bromage, H.; Guzman, M. L.; Nimer, S. D.; Melnick, A.; Neckers, L.; Chiosis, G. Nat. Chem. Biol. 2011, 7, 818-826. doi:10.1038/nchembio.670

14. Darby, J. F.; Workman, P. Nature 2011, 478, 334-335. doi:10.1038/478334b

15. DeBoer, C.; Meulman, P. A.; Wnuk, R. J.; Peterson, D. H. J. Antibiot. 1970, 23, 442-447. doi:10.7164/antibiotics.23.442 
16. Whitesell, L.; Mimnaugh, E. G.; De Costa, B.; Myers, C. E.; Neckers, L. M. Proc. Natl. Acad. Sci. U. S. A. 1994, 91, 8324-8328. doi:10.1073/pnas.91.18.8324

17. Clevenger, R. C.; Raibel, J. M.; Peck, A. M.; Blagg, B. S. J. J. Org. Chem. 2004, 69, 4375-4380. doi:10.1021/jo049848m

18. Tsaytler, P. A.; Krijgsveld, J.; Goerdayal, S. S.; Rüdiger, S.; Egmond, M. R. Cell Stress Chaperones 2009, 14, 629-638. doi:10.1007/s12192-009-0115-z

19. Immormino, R. M.; Kang, Y.; Chiosis, G.; Gewirth, D. T. J. Med. Chem 2006, 49, 4953-4960. doi:10.1021/jm060297x

20. He, H.; Zatorska, D.; Kim, J.; Aguirre, J.; Llauger, L.; She, Y.; Wu, N.; Immormino, R. M.; Gewirth, D. T.; Chiosis, G. J. Med. Chem. 2006, 49, 381-390. doi:10.1021/jm0508078

21. Biamonte, M. A.; Shi, J.; Hong, K.; Hurst, D. C.; Zhang, L.; Fan, J.; Busch, D. J.; Karjian, P. L.; Maldonado, A. A.; Sensintaffar, J. L.; Yang, Y.-C.; Kamal, A.; Lough, R. E.; Lundgren, K.; Burrows, F. J.; Timony, G. A.; Boehm, M. F.; Kasibhatla, S. R. J. Med. Chem. 2006, 49, 817-828. doi:10.1021/jm0503087

22. Andrés, J. M.; Manzano, R.; Pedrosa, R. Chem.-Eur. J. 2008, 14, 5116-5119. doi:10.1002/chem.200800633

23. Du, Y.; Moulick, K.; Rodina, A.; Aguirre, J.; Felts, S.; Dingledine, R.; Fu, H.; Chiosis, G. J. Biomol. Screening 2007, 12, 915-924. doi:10.1177/1087057107306067

24. Schulte, T. W.; An, W. G.; Neckers, L. M. Biochem. Biophys. Res. Commun. 1997, 239, 655-659. doi:10.1006/bbrc.1997.7527

25. Hawley, T. S.; Hawley, R. G., Eds. Methods in Molecular Biology: Flow Cytometry Protocols, 2nd ed.; Humana Press Inc.: Totowa, NJ, 2004. doi:10.1385/1592597734

26. O'Brien, J.; Wilson, I.; Orton, T.; Pognan, F. Eur. J. Biochem. 2000, 267, 5421-5426. doi:10.1046/j.1432-1327.2000.01606.x

\section{License and Terms}

This is an Open Access article under the terms of the Creative Commons Attribution License (http://creativecommons.org/licenses/by/2.0), which permits unrestricted use, distribution, and reproduction in any medium, provided the original work is properly cited.

The license is subject to the Beilstein Journal of Organic Chemistry terms and conditions:

(http://www.beilstein-journals.org/bjoc)

The definitive version of this article is the electronic one which can be found at: doi:10.3762/bjoc. 9.60 